\title{
An In-Depth Study of the Evolution of Literacy to a New Phenomenon Called Functional Literacy: A Review Approach
}

\author{
Mohammad Danish chishti', Dr. ReshmaNasreen², Nazia Hasan khan ${ }^{3}$
}

\author{
${ }^{1}$ Senior Research Fellow, School of Management studies, JamiaHamdard University, New Delhi \\ ${ }^{2}$ Associate Professor\& H.O.D, School of Management studies, JamiaHamdard University, New Delhi \\ ${ }^{3}$ Assistant Professor, Department Of Management, Maharaja Agrasen PG College, Bareilly, U.P
}

\begin{abstract}
This paper is an in-depth study of an important phenomenon of the society that is literacy. Through this paper a thorough study regarding literacy, its concepts, definitions, measures, development and its socioeconomic aspects, have been studied. During this study, it has been observed that over a period of time literacy has come out as battle in developing as well as developed countries. That has been calculated on the basis of cost incurred as a ratio of GDP to different countries. Over significant time duration literacy has been molded into a new term coined as functional literacy thereby making it necessary to go into the depth of such emerging concept in different fields of interest such as Management, banking, health, employment, IT etc. It is noteworthy that functional literacy as concept has proved its importance globally therefore through this paper, a review has been conducted about its global extent, its practical viability, its significance for marketers while deciding on communication strategies etc. lastly the due importance has been given to Indian market place as well as to different literacy programs run by Government of India for the promotion of functional literacy.
\end{abstract}

Key word: Functional literacy, literacy, NLM (National literacy mission).

\section{Introduction}

Literacy is very important aspect of human life.This enables a person to function properly in his/her daily life activities.Reading and writing skills are consideredas key for never ending learning process in a society where job requirements vary time to time (Miller, 1988). In daily life a person comes across several situations where his reading and writing skills help him to overcome his daily challenges. Inability in both these literacy skills drags him in a perplexed situation where decision making becomes difficult. Literacy makes a person enable to actively participate in society where most of the activities and transactions are based on written documents.

Earlier researches has indicated that literacy skills are partly developed in early child hood (Larrick, Illiteracy starts too soon, 1987)(IRA, 1986).It is also been stated that Characteristics of home environment such as pattern of interaction, pattern of language, value given to literacy, learning activities by a child and family may mediate the acquisition of literacy (Fox, 1990).

The United States of America ranks fortyninth among 159 members of United Nations in its average literacy (Larrick, Illiteracy starts too soon , 1987). The number of adults who are not functionally literate in U.S is estimated to be 54.64 million(Hunter C. S., 1979).Even About one fifth of all young adults and one half to one third of minority young adults in U.S read the eight-grade level(Kirsch I. , 1986).Daedalus the journal of American academy of arts and science devoted the spring 1990 issue to study the problem of literacy in America.The journal quotes joseph murphy, chancellor, city university of New York saying "there are as many as 60 million illiterate and semi illiterate adults in America today". A leading German magazine "stern" points out that even the United Kingdom, "one out of five adults in the land of William Shakespeare and harry potter is practically illiterate or has problems counting money in the purse". According to Daniel a Wagner director literacy research Centre at the University of Pennsylvania, over one billion individuals globally, nearly $25 \%$ of today's youth and adults can't read.

Studies in the most advanced countries notably the united states, Denmark, Japan during the period of economic growth and development suggest that there has been a significant relationship between economic growth and quality of formal education provided to their citizens (Thompson, 1981).The adult literacy was undertaken by many developed countries between 1950 and 1980(Abadze, 1994).The education for all conference 1990 was the main impetus for the campaign for adult literacy after that time.(Cunnings, 1992)Asserts that the level of literacy acquired during adult literacy classes tend to show that learner could read and write. Even Low level of literacy have been linked to low productivity high unemployment low earning and high ratio of welfare dependency and teenage parenting all of which are common measures of the socio economic wellbeing of a society(Berlin, 1988). It is expected that both cognitive/behavioral and educational 
factors will be more strongly predictive of literacy than family circumstances.(Furstenberg, JUNE 1994).Through the outcome of the studies discussed above we can conclude this discussion by saying that there is significant extent of illiteracy prevalent globally. The next section will take you through the concepts and definitions proposed by various authors to better understand the concept.

\section{Concepts/Definitions Of Literacy}

Thereare numerous concepts and definitions given about literacy but no consensus has been reached up to a particular definition of literacy. Some of the definitions are as follows.

Literacy the ability to communicate in print is very important aspect of learning world wide(Mpofu, 1995)(Bhola, 1984)(ARKO A. D., 2009)has observed that literacy in the acquisition of knowledge and skills in reading and writing that enables a person to engage him efficiently in any activity. Reading and writing of letters, signing of cheques, observing danger warning in the street and at work place and reading books are some of the activities identified by Bhola (1984). The definition of (Coombs, 1985)is centered on development, who has emphasized that literacy could liberate the poor and uneducated people everywhere from ignorance, disease, and hunger.(Davidson, 1990)Argued that literacy is necessary for the individual to enable him to be very effective in economic, socio-political, educational, cultural, and environmental issues.

The Ghana statistical survey (cited in OSCI 1992)(ARKO A. D., 2009 )has defined a literate person as one who "can read and write with understanding, a letter in any language". Literacy is defined as in Indian census operations, is the ability to read and write with understanding in any language. A person who can merely read but cannot write is not classified as literate(Indian census report, 2011)

According to (Bormuth, 1975) literacy is the "ability to exhibit all of the behaviors a person needs in order to respond properly to all reading tasks" Literacy helps people understands decontextualized information and language verbal as well as written. It paves the way for further learning and as stated in article 1 of the world declaration on education for all (Jontien Thailand 1990)(Literacy: the core of Education for All-Chapter 1, 2006).and reiterated in Dakar (Senegal 2000) literacy and numeracy are essential learning tool of basic education.

As a concept literacy has proved to be dynamic and complex(Unesco, 2006).

There are numerous definitions discussed but several factors make it difficult to reach at a concise definition of literacy. Such factors are inconsistent standards, changing societal demands and individual evaluation measures(Harrison-Walker, The import of illiteracy to marketing communication, 1995)

Table list of definitions

\begin{tabular}{|l|l|}
\hline Definition & Author \\
\hline $\begin{array}{l}\text { Literacy is an individual's ability to read, write and speak in English } \\
\text { and compute and solve problem at level of proficiency necessary to } \\
\text { function on the job and in the society to achieve one's goal and to } \\
\text { develop one's knowledge and potential. }\end{array}$ & $\begin{array}{l}\text { (Harrison-Walker, The Import of illiteracy to } \\
\text { marketing communication, 1995) }\end{array}$ \\
\hline $\begin{array}{l}\text { Literacy is using printed and written information to function in } \\
\text { society to achieve one's goals and to develop one's knowledge } \\
\text { potential. }\end{array}$ & (Jae, 2004) \\
\hline $\begin{array}{l}\text { Literacy is the ability to understand and employ printed information } \\
\text { in daily activities at home, work and in the community. }\end{array}$ & (Chingona W, 2005) \\
\hline Literacy is set of decoding and encoding skills. & (Adkins N. \&., 2005 a) \\
\hline $\begin{array}{l}\text { Literacy is practice involving the active constructions and } \\
\text { negotiations of meaning from the text and in a specific social } \\
\text { setting. }\end{array}$ & (Adkins o., 2005a) \\
\hline $\begin{array}{l}\text { A literate person is someone who can with understanding both read } \\
\text { and write a short statement on his/her everyday life. }\end{array}$ & (UNESCO, Literacy for life, 2006) \\
\hline $\begin{array}{l}\text { literacy is the " ability to exhibit all of the behaviors a person needs } \\
\text { in order to respond properly to all reading tasks" }\end{array}$ & Bormuth (1975) \\
\hline $\begin{array}{l}\text { Literacy the ability to communicate in print is very important aspect } \\
\text { of learning world wide }\end{array}$ & Mpofu (1995) \\
\hline $\begin{array}{l}\text { Literacy is the ability to read and write with understanding in any } \\
\text { language. A person who cannot merely read but cannot write is not } \\
\text { classified as literate. }\end{array}$ & Indian census operation(2011) \\
\hline
\end{tabular}

After going through definitions it has been observed that some of the authors have similar way of perceiving the term 'literacy' but some of them presented the literacy in his own way. Here the question arises that how this literacy is being measured so that it could be easily understood. 


\subsection{Measures of literacy}

The emphasis on the skills that are necessary to fulfill one's role as a member of society recognizes the social context of literacy skills (Hunter C. S., 1979). The ability to use written documents continues an important part of daily functioning in today's society.(Guthrie, 1986).Document literacy might be distinguished from prose literacy because of the distant forms of grammar and syntax(Kirsch I. S., 1988).

\subsection{The New Measures of Literacy}

The United Nations house hold capability survey program suggests an alternative approach, more relevant to developing countries. The aim of this survey is to provide a literacy classification scheme designed for policy planning.(WAGNER, 1995)(Wagner D. A., 1990a)Classified people level into four groups according to their literacy.

a.) Non literate - a person may be defined as non-literate who is unable to read and write a text with understanding and write a short text in a significant national language and who is not able to recognize words as signs and documents in every day contexts and can't perform some specific task like signing his or his name or recognizing the sense of public sign.

b.) Low literate- a person may be differentiated as low literate who cannot read a text withproper understanding and write a short text in significant national language but who can understand words as signs and documents in every day context and can do such tasks as signing his or her name or understanding the meaning of public sign.

c.) Moderate literate-a person is called moderately literate who can read a text with understanding and can write short sentences in significant national language but with some extent of difficulty and commit numerous errors.

d.) High literate- a person is considered as highly literate who can read a text with understanding and write a small text in significant language but with little difficulty.

In the above discussion it has been observed that literacy has been discussed in the context of reading and writing. But there is something missing that is the numeracy skills. The inclusion of numeracy as a new phenomenon found its place in the discussion of problems of illiteracy $(\mathrm{Gal}$, 1993).Earlier researchers from developing countries didn't pay much attention to this area. While UNESCO 1978 includedreading,writing and calculation in its definition of functional literacy.

\subsection{Literacy and development}

As far as the literacy and development is concerned, most of the researchers consider literacy responsible for development. It is perceived something good for individual and society (Daniel Wagner).There are number of benefits which can be derived from literacy.

There are six values which are transferred from literacy which give a literate person an extra edge over who is not literate(Gray W. , 1990). These values are as follows.

1). Literacy assist to meet most of the practical need of daily life activities.

2). Literacy helps in forming the standard of living through getting important printed information pertaining to health, sanitation, child care etc.

3).literacy improves economic status and economic wellbeing through involving in those business activities which depends on knowledge of reading and writing.

4).literacy enables and strengthens individual to be part in many sole and group activities, that require reading and writing.

5). Literacy enables one to learn about community activities through reading.

6). Literacy enables one to meet one's civic duties such as voting.

There are five general rationales of literacy which have been put forwarded over the years in the different specific context of national economic development plan (Wagner D. A., 1992)(Lind, 1990)(Tanguiane, 1990)(Haddad, 1990).These rationales are economic, social, political, endogenous and exogenous.

\subsection{Myths about literacy and development}

1). Literacy changes the thinking of human being, their logical abilities and their intelligence. This model of 'Mental Consequences 'has been known since past centuries. There is no significant proof to assist such a statement. Even then this claim remains published in present time.(Scribner, 1981)

2). Literacy tends to human modernization and changing of attitude about 'development'. International development work focuses on this result of literacy. It has not been completely mentioned whether literacy shows any kind of particular effect. There are many indications which have shown that years of schooling tend to attitudinal changes but unsuccessful to determine how schooling impact attitude. Many of these studies are hindered by confounding variable such as economic and social status. 
3).literacy strengthens democratic ideal and improves national productivities, this positive correlation only have ancillary support in the earlier studies. Democracy can't be experienced without informed populace. To get information about international and national events, printed source of material is the only way. In some of the developing countries, due to low literacy, television and radio supported printed material as the main source of outside information.

\subsection{The Economic and Social Cost of Illiteracy}

III. Literacy And Its Socio-Economic Aspects

Over a period of time, there are many studies been taken up to calculate the economic value on the cost of illiteracy in different nations.But the problem remains unresolved about the methodology to be used. The illiteracy cost the global economy more than USD1 trillion dollars.Every year at least one in five people fights with illiteracy.It is shocking to here that more than 796 million people in the world can't read and write. Around 67 million children do not have reach to primary school education.0.72million miss out on secondary school education.

According the finding of the previous report (Anthony Cree A. k., 2012)

1).The cost of illiteracy to the global economy is estimated at USD $\$ 1.19$ trillion

2).The cost of illiteracy is economic terms discuss about lost earning and limited employability, lost to business opportunities, lost wealth creation opportunities for individuals and business, lower technology skills capability in future.Cost of illiteracy is social terms comprises of in terms of cost of health, crime, welfare.

Table:Cost Of Illiteracy In Developed Countries

\begin{tabular}{|c|c|c|}
\hline Country & GDP (billion) & Cost of illiteracy \$(billion) \\
\hline Australia & $\$ 917.70$ & $\$ 18.35$ \\
\hline Austria & $\$ 351.40$ & $\$ 7.03$ \\
\hline Belgium & $\$ 412$ & $\$ 8.24$ \\
\hline Canada & $\$ 1,389$ & $\$ 27.78$ \\
\hline Czech Republic & $\$ 272.20$ & $\$ 5.44$ \\
\hline Denmark & $\$ 208.80$ & $\$ 4.18$ \\
\hline Estonia & $\$ 26.93$ & $\$ 0.54$ \\
\hline Finland & $\$ 195.60$ & $\$ 3.91$ \\
\hline France & $\$ 2,214$ & $\$ 44.28$ \\
\hline Germany & $\$ 3,085$ & $\$ 61.70$ \\
\hline Greece & $\$ 305.60$ & $\$ 6.11$ \\
\hline Hong Kong & $\$ 353.70$ & $\$ 7.07$ \\
\hline Hungary & $\$ 195.90$ & $\$ 3.92$ \\
\hline Iceland & $\$ 12.33$ & $\$ 0.25$ \\
\hline Ireland & $\$ 182.10$ & $\$ 3.64$ \\
\hline Israel & $\$ 235.10$ & $\$ 4.70$ \\
\hline Italy & $\$ 1,826$ & $\$ 36.52$ \\
\hline Japan & $\$ 4,389$ & $\$ 87.78$ \\
\hline Luxembourg & $\$ 43.55$ & $\$ 0.87$ \\
\hline Netherlands & $\$ 705.70$ & $\$ 14.11$ \\
\hline New Zealand & $\$ 123.30$ & $\$ 2.47$ \\
\hline Norway & $\$ 264.50$ & $\$ 5.29$ \\
\hline Poland & $\$ 765.60$ & $\$ 15.31$ \\
\hline Portugal & $\$ 246.90$ & $\$ 4.94$ \\
\hline Singapore & $\$ 314.50$ & $\$ 6.29$ \\
\hline Slovak Republic & $\$ 126.90$ & $\$ 2.54$ \\
\hline Slovenia & $\$ 58.56$ & $\$ 1.17$ \\
\hline South Korea & $\$ 1,554$ & $\$ 31.08$ \\
\hline Spain & $\$ 1,411$ & $\$ 28.22$ \\
\hline Sweden & $\$ 379.40$ & $\$ 7.59$ \\
\hline Switzerland & $\$ 340.50$ & $\$ 6.81$ \\
\hline UnitedKingdom* & $\$ 2,250$ & $\$ 127$ \\
\hline United States & $\$ 15,040$ & $\$ 300.80$ \\
\hline TOTAL & & $\$ 803.94$ \\
\hline
\end{tabular}

* Note: UK figure is measured at $3.75 \%$ of GDP based on a detailed study on this country in the interim report

Source:(Anthony Cree A. k., 2012) 
Table for the Cost of illiteracy in some of the emerging countries

\begin{tabular}{|l|l|l|}
\hline Country & GDP (billion) & Cost of illiteracy \$(billion) \\
\hline Argentina & $\$ 709.70$ & $\$ 8.52$ \\
\hline Brazil & $\$ 2,284$ & $\$ 27.41$ \\
\hline Egypt & $\$ 515.40$ & $\$ 6.18$ \\
\hline India & $\$ 4,463$ & $\$ 53.56$ \\
\hline Pakistan & $\$ 488$ & $\$ 5.86$ \\
\hline Russia & $\$ 2,373$ & $\$ 28.48$ \\
\hline South Africa & $\$ 554.60$ & $\$ 6.66$ \\
\hline
\end{tabular}

Source:(Anthony Cree A. k., 2012)

\subsection{Battle of literacy in developed and developing nations}

As we know thatdeveloped countries are technology driven.People living in such countries use to come across a situation where there literacy skills are required either in case of reading a sign or symbol running on an electronic sign board, or a condition of using electronic high end gadgets for personal use where typing in English or in native language needed, reading numbers showing on electronic display device for people while waiting in a que.These very situations are not easy to overcome for illiterate people staying in developed countries. There could probably a story of person who made it to a high school but dropped at early.It might be possible that he would have been a slow learner. It might be that he had a problem at home. After leaving school he made a huge effort to hide that he can't read but effects of poor literacy came to him in practical world.

Think in hypothetical situation where a person comes home with wrong food items just because of he is unable to read a label or understands it, or being unable to read the newspaper, or not realizing that somebody has made him agreed to wrong terms and conditions for a particular service availed.

In developing countries, think about a person who is the poorest of poor, living in a very remote place. His/her fulfillment of daily need items force him to visit nearby town area regularly, where he comes across number a situations where decision making is based on the ability to read, write and numeracy skills. Then he realizes the importance of literacy.

\subsection{Concepts of functional literacy.}

\section{Functional Literacy And Its Global Perspective}

As a concept, functional literacy came into existence in the USA \& U.K IN 1970s when it was realized that there are number of adults and increasing who found it difficult to deal with some of the reading and writing tasks they come across in their everyday life(UNESCO, 2008). Though the fundamental education talks about reading, writing and arithmetic skills but functional literacy has a scope which goes beyond. Functional literacy has several meaning both in social and technical usage (ARKO A. D. 2009).

Functionally literate person should be able to participate in his social and cultural activities with the help of his literacy skills(ARKO A. D. 2009).Functionally literate person should use reading, writing and arithmetic skills for his own development and development of his community. Functional literacy contributes in the learning to read write about daily life activities, problems and needs. Functional literacy is based on learner's problems, interests, needs with the hope of finding solution for them. Functional literacy is also counted as a difference between the individual's current level of literacy and the literacy demanded by his environment.The ability to read and write and make some numerical calculation could improve development for example making someone able to identify his hospital card in order to attend the hospital could promote his good health. Productivity and income levels could go up, which increases purchasing power. Fundamental need could be satisfied and standard of living is raised.

According the various special tests, literacy may be best understood in terms of its functional utility social domain that's why a term proposed 'functional literacy' (Hunter and Harman 1979, Levine 1982)

\subsection{Definitions of functional literacy}

There are numerous definitions given by various authors in different context. Someof the definitions are as follows.(Addo-Adeku, 1992).He has defined functional literacy as "abuilt in mechanism which uses the participating techniques in dealing with identifiable groups. Such group would need the skills of reading, writing and reckoning to enable them to perform efficiently in their life"(p.11).According to Addo-Adeku 1992 "a functionally literate person should be able to read and write and understand simple statements relating to his daily activities, work environment and his community". According to UNESCO 1978 “ functionally literate person as one who is able to engage in all those activities in which literacy is required for effective functioning of his group and community". Functional literacy is not limited to reading, writing, and reckoning. It should also contribute to prepare individual for social, civic and economic roles. (Dorvlo, 1992).Hager, 1992 has emphasized that functional literacy aims to promote a man's centric development with a holistic view. The united states government (as cited in UNESCO 1983) has defined functional literacy as "possession of the 
essential knowledge and skills that enables an individual to function in his environment, at home, in the community and in the work place"(p.4). UNESCO also defines functional literacy as "measured as assessing reading, writing and mathematical skills in the various domain of social life which influence individual identity and insertion into society. From this perspective, literacy involves not only reading and writing but also the acquisitions of the skills necessary for effective and productive performance with society".UNESCO 1978 also defined 'functional literacy as "a person is functionally literate who can engage in all those activities in which literacy is required for effective functioning of his group and community and also for enabling him to use reading, writing and calculation for his own and community development".(Gray W. , 1956)Suggested that "a person is functionally literate when he has acquired the knowledge and skills in reading and writing which enables him to engage effectively in all those activities in which literacy is normally assumed in his culture and group". Viswanathan and Gau 2005 suggest that functional literacy makes a linkage with nation of literacy and numeracy to adequate functioning in day to day life.Gal, 2002:21 defined numeracy as the capacity and propensity to effectively and critically interact with the quantitative aspects of adults life. As far as the behavioral aspects of definition is concerned, literacy proficiency in terms of a mode of adult behavior is judged on the basis of being able to use printed information which functions in a differentcontext throughout society(Boudard\& Jones 2003:193)(Boudard, 2003). For the people to function in a society, the kind and level of literacy is understood in different ways in different places(UNESCO,2008:15). Many of the researchers have talked about and given reasoning for the plurality of literacies due to the important differences of what adult life demands across economies and cultures and also emphasized that skills required to catch written and verbal meaning are dependent on context.(Viswanathan et al(2005:15) for example, the language and numeracy skills required by consumers in the village in south India is different for those required in north India. functional literacy is defined in the literacy volunteers of America tutor's video guide as " lacking the literacy skills and knowledge needed for coping successfully with day to day living”. According lee (1988) functionally illiterate people are limited in their reading, writing, speaking, listening and mathematical skills. Many a times it has been observed that typically consumer involves in reading labels for product information, navigating the complex market place through using store signage, calculating price to ascertain the value(Gau\& Viswanathan. 2008).

Functionally illiterate individuals cannot apply their basic reading, writing and numeric skills to accomplish tasks that are important to make informed choice. Such tasks may count as follow.

1). Balancing a cheque book

2). Reading a medicine label

3). Reading a nutritional label on a food product

4).Filling out a job application

5). Reading a bank statement

6).Filling put a home loan application

7).Understanding the product advertisement

$8)$. Understand the information given on a product label.

This inability also limits them to engage in activities that require criticalthinking or firm base of literacy and numeracy skills. These activities could be

1).Understanding Government policies and voting in elections.

2). Using a computer to make an online transactions.

3).Calculating the cost and potential return on an investment.

\subsection{The objectives of functional literacy}

After going through much of the discussion about functional literacy researchers have come to the conclusion that there are some of the objectives of functional literacy for which it is needed. These objectives are as follows.

1).To enable the person to meet his/her social or personal need through honing their abilities to deal competitively with everyday life in a literate environment.(ARKO, Augustus Daniel, ADDISON, Kofi, 2009)

2).To equipspeople with knowledge, attitude and skills that will raise their standard of life in their community. (ARKO, Augustus Daniel, ADDISON, Kofi, 2009)

3).To enable people enhance upon their occupational skills with the assistance of functional literacy.(ARKO, Augustus Daniel, ADDISON, Kofi, 2009. 
Table: Definitions of functional literacy/Illiteracy.

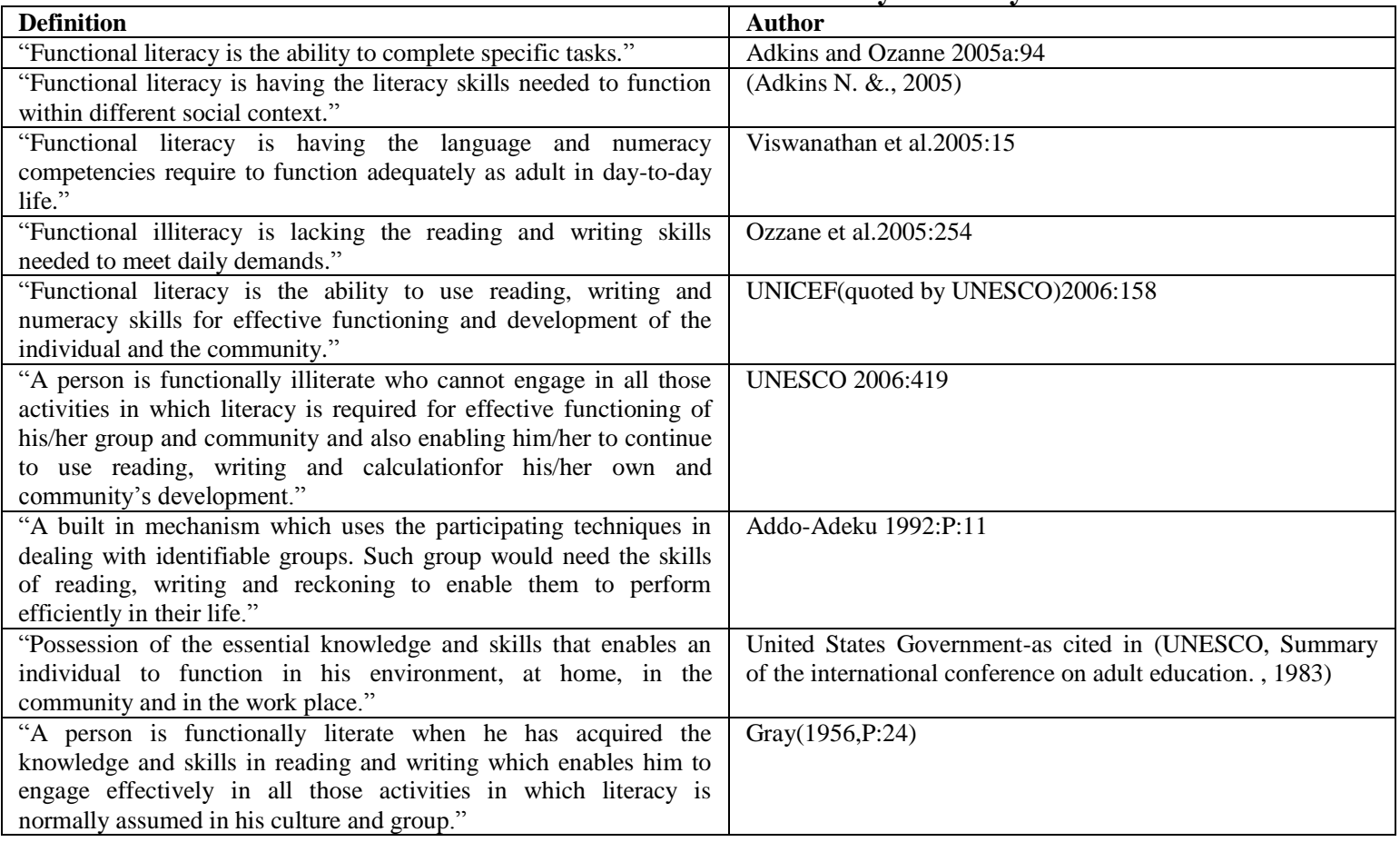

All of the above definitions show that functional literacy is not only about reading and writing.It enables a person to meet daily life challenges through meeting their demands and complete specific tasks with in a specific context.This study shows that literacy skills needed to function in class room are different from those required to function in the marketplace.

Following UNICEF (Quoted by UNESCO, 2006:154 as well as Adkins andOzanne, 2005:94, for the objective of this research, functional literacy is defined as the ability to use reading, writing and numeracy skills to successfully complete the shopping tasks. Functional illiteracy therefore means that individual consumer is not able to use reading writing and numeracy to successfully complete shopping tasks or consumer's decision making process.

\subsection{A Global Perspective on the Extent of Functional Illiteracy}

UNESCOcame into existence in 1946, since then it has taken all the initiatives and global efforts to promote literacy on national, regional and international agencies(UNESCO, Global digest, 2008). Literacy is very important aspect because it's a personal development tool and a source of social and human development and also a human right(UNESCO, lamp, 2009). There are some of the key elements have to be taken into consideration in any of the discussion about literacy and its development(UNESCO,2009:16). These elements are as follows

1). The centrality of using text.

2). The need to use text with good understanding.

3).Not restricted to text but also include numeracy part.

4).Need to search all these issues embedded in everyday life experience.

Data on the extent of functional illiteracy in the developed and developing countries

\begin{tabular}{|l|l|}
\hline Area & \% population of literate \\
\hline World & 81.9 \\
\hline Countries in transition & 99.4 \\
\hline Developed countries & 98.7 \\
\hline Developing countries & 76.4 \\
\hline
\end{tabular}

Source:(UNESCO, Literacy for life, 2006)

UNESCO has given the statistics of functional literacy which is mostly based on estimates.Due to which its global extent is not easy to determine (UNESO, 2006:73).In reality these pictures of literacy statistics show the performance of national education system and power of country's human resource.Different countries define it in a different way. Some of them do comparative assessment about literacy. Some other countries define on the basis of data collection through population census, data on school enrollment or rate of completionof 
census occur after 10 years and house hold surveys are conducted after every three to five years. (UNESCO, 2008:10).For e.g.In many countries, to know about literacy status of a person, a general question is being asked that is"are you literate or not?" or "can you read a simple sentence with understanding?" and most of the time the answer about whole of the family members' literacy is given by the head of the family or household (UNESCO,2008:11).According the UNESCO, (2006:18, )There are 771 million illiterate adult, that is $18 \%$ of the world adult population. These statistics are based on the data collected between 2000 and 2004 worldwide.In United States, functional illiteracy lies from one fifth to quarter of the population(Viswanathan and Gau, 2005:187).Even in other industrialized countries, estimate of functionally illiterate are good in number.(Viswanathan et al, 2005:16).The global adult literacy rate for the population aged 15 years and above was 84\% in 2011(Institute of statistics, JUNE 2013).In absolute numbers 774 million adults lack basic literacy skills in 2011(UNESCO Institute Of Statistics; May 2013:P9).Three quarter of the global illiterate population lived in two regions South And West Asia. In which there are 407 million or more than half of all illiterate world Wide and Sub-Saharan Africa with 182 million illiterate adults, around one quarter of the global total. Two regions, central and eastern Europe and central Asia were at or near universal literacy, with adult literacy rate of 99\% and 100\% respectively (UNESCO institute of statistics, May 2013, P:8). In south and west Asia, the adult literacy rates were below the global average that is 63\% and 59\% respectively.(UIS, May 2013:P:8)

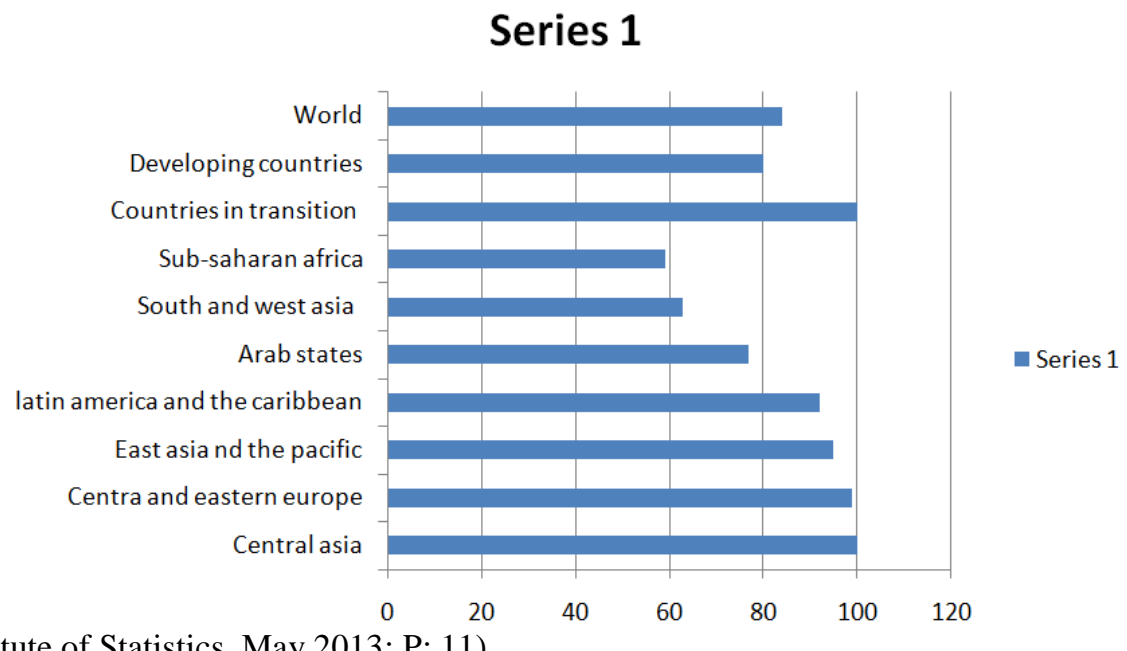

(UNESCO Institute of Statistics, May 2013: P: 11)

In spite of persistent illiteracy, Adult literacy rates have increased over the past two decades in all regions.In 1990, global adult literacy rates was $76 \%$, in 2000 was $82 \%$ and in 2011 It became $84 \%$.In 2002, the United Nations proclaimed the UN literacy decade for the years 2003 to 2012(UN general assembly, 2002a, 2002b).In three regions-Arab States, South \& West Asia and Sub Saharan Africa-till 1990, there were approximately one half of all adults were illiterate.But over a period of time these regions expressed the progress during the period 1990-2011.Arab states experienced 22\% increase in adult literacy rate, south and west Asia 16\% but sub Saharan Africa there was a modest growth of 6\% only (UIS, May 2013: P:11).

\begin{tabular}{|l|l|l|l|}
\hline EFA region & $\begin{array}{l}\text { 1990(1985-1994 Census } \\
\text { decade) }\end{array}$ & $\begin{array}{l}\mathbf{2 0 0 0}(1995-2004 \text { Census } \\
\text { decade) }\end{array}$ & $\begin{array}{l}\text { 2011(2005-2014 Census } \\
\text { decade) }\end{array}$ \\
\hline Arab states & $\mathbf{5 5 \%}$ & $\mathbf{6 8 \%}$ & $\mathbf{7 7 \%}$ \\
\hline Central and eastern Europe & $\mathbf{9 6 \%}$ & $\mathbf{9 7 \%}$ & $\mathbf{9 9 \%}$ \\
\hline Central Asia & $\mathbf{9 8 \%}$ & $\mathbf{9 9 \%}$ & $\mathbf{1 0 0 \%}$ \\
\hline East Asia and the pacific & $\mathbf{8 2 \%}$ & $\mathbf{9 2 \%}$ & $\mathbf{9 5 \%}$ \\
\hline $\begin{array}{l}\text { Latin America and the } \\
\text { Caribbean }\end{array}$ & $\mathbf{8 6 \%}$ & $\mathbf{9 0 \%}$ & $\mathbf{9 2 \%}$ \\
\hline South and west Asia & $\mathbf{4 7 \%}$ & $\mathbf{5 9 \%}$ & $\mathbf{6 3 \%}$ \\
\hline Sub Saharan Africa & $\mathbf{5 3 \%}$ & $\mathbf{5 9 \%}$ \\
\hline
\end{tabular}

Source:(UNESCO Institute of Statistics, May 2013: P: 11)

Literacy rates are very important for many stakeholders. The next two sections will give the idea of importance of functional literacy for a country and for a marketer. 


\subsection{The practical implication aspects of functional illiteracy for a country.}

Researchers have already acknowledged the role and importance of education for the growth and development of individual and security as a whole(Adkin \&Ozanne,2005b:154).Understanding the behavioral aspect of functionally illiterate consumer not only contributes to marketing practices but also to the policy designing because these consumers are linked with poverty, health problems, deprivation of voting right etc. (Jae\& Delvecchio,2004:352)

Countries having high level of illiteracy find competitive disadvantage in global economy because low literacy skills are considered as a barrier to economic growth and development.(Sharma Quoted by Adkins \&Ozanne, 2005b:153).It has been discussed that thinking of literate society is abstract compared to non-literate ones. Andit's lacking impact the levels at which societies react to their environment.(Viswanathanet al.2005:16)

Literacy strengthens the ability of individuals, family and communities by which they can be in a position to take advantage of health education, political, economic and cultural opportunities.(UNESCO: 2006:19).India is aware of the disadvantage of having the significant portion of its population being functionally illiterate. The implementation of mass literacy campaign reveals this which is discussed more in detail in later in this section.

\subsection{The Importance of Functional Literacy For The Marketer}

As it has been observed that society is increasingly becoming educated. Marketer must accept and recognize that there is a significant and sizable group of consumers which are functionally illiterate (laudon\&Dellabitta, 1993:51).It is important to note that countries like India, more than $25 \%$ of adult population is illiterate (Statistics, Census 2011). According to the census of India literacy rate has been reported as $74.04 \%$, with an increase of $14 \%$ to that in 2001.Report also says that literacy rate of rural women increase by $26 \%$ in the last decade which is the outcome of literacy mission of government of India(literacy and education chapter3).According to Viswanathan et al(2009:11), there are approximately 800 million people are lie at the top of economic pyramid, Among the 6.5 billion member of the human community.According to Harrison and walker (1995:61), illiteracyneedsimmediate attention of marketer. If they want to continue to organize their activities and function effectively in the field of marketing communication.For marketer's point of view, it's important to have a concern about "one's reading ability to perform real life tasks described in print-the ability to process information"(Lee 1988).

Conventionally it has been assumed that consumers that lie in the bottom of pyramid do not have a reach to advanced or luxury products but there are evidences that describes about the market places at this level are profitable and socially rewarding for the companies (Weidner et al 2009:11).In the emerging economies, having functional illiteracy, with increasing standard of life and consumer spending, the purchasing power of functionally illiterate consumer worldwide is significant and ready to take leap (Viswanathan et al 2005:16). It has been proposed that there is dearth of the understanding of the unique aspects of this consumer market place and about the market strategies (Weidner et al 2009:12).

For the policy formulation perspective, the assessment of consumers' knowledge, their decision making capabilities are required.Policies help to address information in market, product choices and obstruction to market place participation (Teil, levy \& Derby in Ringold, 2005:202). Sometime market place conditions restrict these consumers' chances to participate completely in the shopping environment. Marketers have to make adjustment in advertising messages, packaging and usage instructions for functionally illiterate consumers because of their lower level of information processing skills (laudon and Dellabitta 1993:51).Functionally illiterate consumer will find it easy to evaluate and select the product having simplified language on their packages and in turn due to the derivation of more satisfaction from the product may lead to repeat purchase (Jae and Delvecchio, 2004:352).Earlier researches have shown that there was a lack of awareness among marketer about the behavior of functionally illiterate consumers (Adkins \&Ozanne, 2005a:153).Millions of functionally illiterate people gave direction to the marketer that their offering are not readable by those consumers. Researches gave idea about this limited ability to read faced by much of the population, should be taken into contemplation of marketers.Text or words on the packaging of the fast moving consumer goods are at the level beyond the comprehension ability of the most of the population. That leads to risk of important product usage.(Jae \&Delvecchio, 2004:351)

\subsection{Functional Illiteracy As Realism In The Indian Emerging Market Place}

More than $80 \%$ of the consumers live in emerging consumer markets.(Steenkemp, 2002).Emerging market vary in human development and national income(S.M. Burgess, 2006).There are plenty of country classification scheme and use of the term "emerging market" has been unpredictable for marketing literature and practices(Batra, 1999),(Peng, 2000).According to financial institution such as ING and Morgan Stanley for a country to be considered as emerging market, it should not meet one or more of the criteria of developed country.That criteria for a developed country is 
1).The country's per capita income has to exceed $\$ 10000$

2). The country has to follow a stable and responsible macroeconomic policy and the market capitalization of publicly traded companies and the volume of shares traded on the stock exchanges have to be "sufficient".

Literacy level and educational attainment are vital indicators of development in a society(State of literacy, provisional population total India, 2011).Attainment of universal primary education is one of the millennium development goals of United Nationsto be achieved by the year 2015 (State of literacy paper chapter 6).Planning commission of India in its eleventh five year plan has also targeted to increase literacy rate of a person age 7 years or more to $85 \%$.And side by side reducing gender gap in literacy to 10 percentage point by 2011-12.(State of literacy paper -chapter 6).Higher level of literacy and educational development lead to greater awareness on the one hand and support people in acquiring new skills on the other.

As per the provisional population total of census 2011, the number of literates and illiterates aged seven and the above are 778454,120 and $272,950,015$ respectively.Literate in 2011 comprises of 74 percent of the total population aged seven and the above compared to 65 per cent in 2001 (Census of India, 2011).According to census of India, for enumeration purpose the person aged 7 and above, who can both read and write with understanding in any language counted as literate (State of literacy paper-chapter 6). In the census prior to 1991, a child below five years of age was compulsorily treated as illiterates(State of literacy paper -chapter 6). The age limit was raised to 7 years on the advice of experts. According to expert the ability to read and write with understanding is not ordinarily achieved until that age (State of literacy paper -chapter 6).

\section{Census 2001}
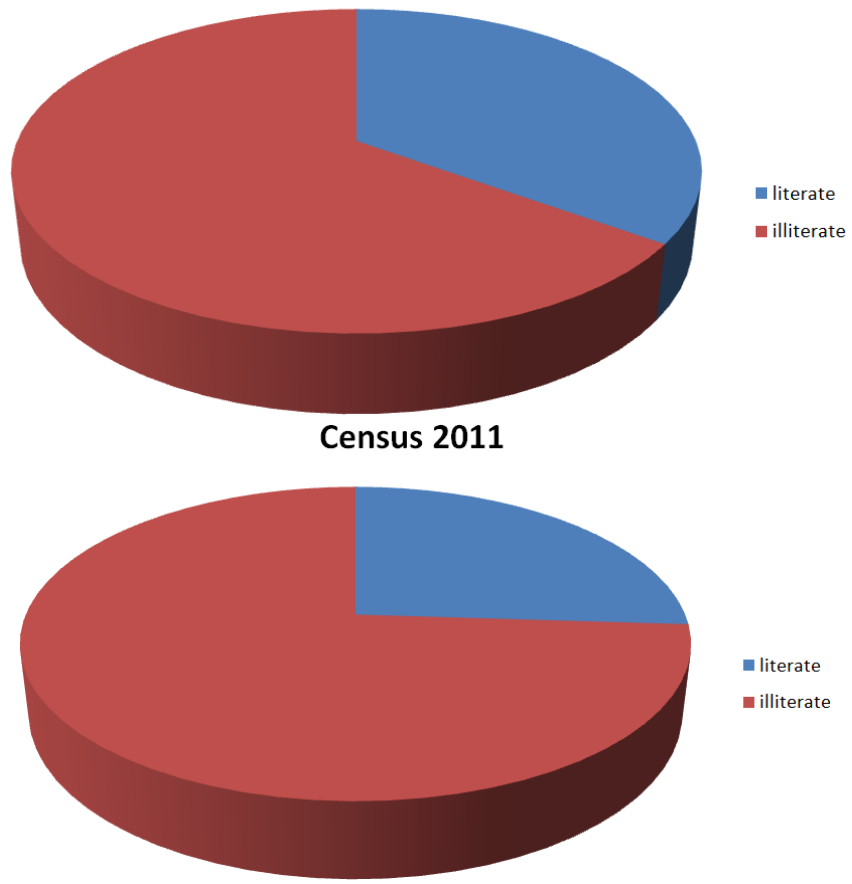

\subsection{Literates and illiterates by gender}

Asper the provisional population totals of census of India2011, the number of person aged seven years and the above is $1051,404,135$ out of total provisional population of 1210,193422.It is motivating to note that 217,700941 literates added during the decade (provisional population total, state of literacy-chapter 6, P: 99).Literacy rate has surged from $64.83 \%$ to 74.04 percent in 2011 with an increase of 9.21 percentage point. The literacy rate of male and female has been $82.14 \%$ and $65 \%$ respectively. (Census India 2011)

\begin{tabular}{|l|l|l|l|}
\hline Literates/illiterates & Persons & Males & Females \\
\hline Population aged 7 and above & 864900041 & 447214823 & 417685218 \\
\hline 2001 & 1051404135 & 540772113 & 510632022 \\
\hline 2011 & 186504094 & 93557290 & 92946804 \\
\hline Increase in 2011 over 2001 & 560753179 & 336571822 & 224181357 \\
\hline Literates & 778454120 & 444203762 & 334250358 \\
\hline 2001 & 217700941 & 107631940 & 110069001 \\
\hline 2011
\end{tabular}




\begin{tabular}{|l|l|l|l|}
\hline \multicolumn{4}{|l|}{ Illiterates } \\
\hline 2001 & 304146862 & 110643001 & 193503861 \\
\hline 2011 & 272950015 & 96568351 & 176381664 \\
\hline Increase in 2011 over 2001 & -31196847 & -14074650 & -17122197 \\
\hline
\end{tabular}

Source-(Provisional population total, India, State of literacy, chapter -6, P: 100)

Ten states and union territories e.g. Kerala, Mizoram, Lakshadweep, Tripura, Goa, Daman \&Div, Puducherry, Chandigarh and NCT of Delhi and Andaman Nicobar Island have achieved literacy rate above 85\% .Which was the target set by planning commission to be achieved by 2011-12(provisional population total, state of literacy-chapter 6: 108).

\section{Adult Education \& National Literacy Mission inIndia.}

Literacy is the backbone of progressive and developing nations like India. A literate nation would be free from any kind of evil practices like slavery but it is tough to remove the scourge illiteracy from this vast country. To convert this tough mission to an achievable one, adult literacy and NLM has been started by Indian government.The fundamental aim of adult education is to provide educational option to those adults, who have missed the opportunity and have passed the age of formal education but now they realize the need for learning of any kind including literacy, basic education, and skill development(Department of school education and literacy). Having the objective of promoting adult education, a series of programs have been introduced since first five year plan. The most noteworthy being the National literacy mission(NLM, 1988), to impart functional literacy to non-literates in the age group of 15-35 years(Department of education-website).By the end of $10^{\text {th }}$ plan period, NLM had made 127.45 million literate, among which $60 \%$ were females. $23 \%$ schedule caste, $12 \%$ schedule STs.597 districts were covered under total literacy campaign of which 502 reached post literacy stage and 328 reached continuing stage.

Adult education in a concurrent subject with both central and state government. At the national level, as autonomous wing of MHRD, National Literacy Mission Authority(NLM) is the Nodal Agency for over All Planning and Management of Adult Education Programs\&Institute (Department of school education and literacy).It was set up in 1988 with the approval of the cabinet as an independent and autonomous wing of the ministry of $\operatorname{HRD}($ The then department of education).

The constitution of India directs the state to make provision for securing the right of children to education with in the limit of its economic capacity and provide free and compulsory education to all children up to age of 14 years by 1960.(Innovative approaches to functional literacy and poverty alleviation, National case study, India, 2001).From 1959 to 1977 various periodical uncoordinated efforts were attempted in the field of adult education in India. The ultimate aim of most of these programs was not only to impart literacy in the ordinary manner but also to provide learners with functionality and awareness.(Innovative approaches to functional literacy and poverty alleviation, National case study, India, 2001).From 1978 to 1990, Centre based programs under the national adult education programs were started. During which national literacy mission came into existence. India has realized that literacy is unavailable component of human resource development.it is a necessary tool for communication and learning for gaining and transferring the knowledge and information. A brief over view of adult education and literacy programs in India since 1959 has been given below.

1.) Gram ShikshanMohim(village literacy movement)- It started in 1959 started in the state of MAHARASHTRA in 1959, on an experiment basis in 25 district with an aim of imparting basic literacy skills with in a period of four month. However program suffered from a lack of systematic follow up and lapsed. (Innovative approaches to functional literacy and poverty alleviation, National case study, India, 2001).

2.) Farmers' functional literacy project-It started in $1967-68$ as a part of green revolution having objective of making farmers functionally literate in high yielding cultivation areas but it had to be stopped due to lack of financial support. (Innovative approaches to functional literacy and poverty alleviation, National case study, India, 2001).

3.) Workers' education- The program was implemented through central board of workers' education and its institutes.in 1977. In 1977 this scheme was reviewed by a group, which recommended adoption of these institutes in adult education programs for workers in urban areas. In implementation of this decision, shirmikvidyapeeth was set up in urban areas of the state.In 1999 this scheme was again reviewed and now these centers provide multivalent adult education to neo-literate and workers in urban as well as rural areas. (Innovative approaches to functional literacy and poverty alleviation, National case study, India, 2001).

4.) Education commission- In 1964-66 on of the significant event in the Indian history of education, came into existence that was the appointment of education commission.one of its important recommendation was that the priority should be given to the eradication of illiteracy and adult education should be advocated through 
'selective' as well mass approach (Innovative approaches to functional literacy and poverty alleviation, National case study, India, 2001).

5.) Functional literacy for adult women- This was started in 1975-76 with an aim to enable illiterate women to acquire functional skills along with literacy to promote awareness about hygiene,nutrition, child care practice and attitudinal changes. The greater emphasis was given to women in the 15-35 age group (Innovative approaches to functional literacy and poverty alleviation, National case study, India, 2001).

6.) The National adult education program (NAED)-As a nation-wideattempt to eradicate illiteracy the national adult education program was started in 1978. The aim of this project was to educate 100 million non-literate adults in the age group of 15-35 years with in time frame of five years. The aim of this NAEP was not only to impart literacy but also to promote social awareness and functionality.(Innovative approaches to functional literacy and poverty alleviation, National case study, India, 2001).

7.) Rural functional literacy project (RFLP) - In 1978, RFLP was started with the support of central government in the rural areas.The 144 farmers' functional literacy project and 60 non formal education projects were merged into it.in each project the maximum number of adult education centers increased up to 300, with 25-30 learners in each centers. (Innovative approaches to functional literacy and poverty alleviation, National case study, India, 2001).

8.) Mass program for functional literacy (MPFL) - This program was financed by the Ministry Of Human Resource Development .This program was operationalized through school students and community on each one teaches one basis.This became discontinued in 1990 (Innovative approaches to functional literacy and poverty alleviation, National case study, India, 2001).

\section{Conclusion}

After going through the vast literature and contemporary studies including various national and international reports about the literacy it is very important to note that after so many years of evolution of literacy this concept is still is in a growing stage. Even after so much of significant researches conducted, researchers have not reached the consensus about the definition of literacy. Through this significant paper researcher has come to a conclusion that literacy as a concept has proved very significant in various aspects. Such as education, social science, economics, management etc. Over a period of time the extension of literacy to functional literacy has become essential for the marketers thereby making this concept very much relevant for the consideration of them therein the marketers consider it while making any kind of communication with their target audience. Census gives the idea about the numbers of literacy levels. But when it comes to the real literacy level it has been found that people find them unable to respond to market stimuli therefore the term functional literacy becomes significant. And it has broadened the scope of the subject.

\section{References}

[1]. (2001). Innovative approaches to functional literacy and poverty alleviation, National case study, India. New Delhi: UNESCO and Indian National commision for cooperation with Unesco.

[2]. Literacy: the core of Education for All-Chapter 1. (2006). Education for All Global Monitoring Report , 31

[3]. Unesco. (2006). 147.

[4]. (2008). UNESCO.

[5]. (2011). Indian census report.

[6]. State of literacy, provisional population total India. (2011).

[7]. Abadze, H. (1994). Adult literacy: Problem-ridden area . World Bank Discussion Papers 2 (3), 410-420.

[8]. Addo-Adeku, K. (1992). A case study of functional literacy programme in the Ga district, greater Accra region of Ghana. Ghana Journal of Literacy and Adult Education. 1(2), 167-182.

[9]. Adkins, N. \&. (2005 a). Critical consumer education: empowering the low literate consumer. Journalof macro marketing 24(2), 15362 .

[10]. Adkins, N. \&. (2005). The low literate consumer. Journal of consumer research, 32, 93-105.

[11]. Adkins, O. \&. (1995 b). The low literate consumer. Journal of consumer research, 153-62.

[12]. Adkins, o. (2005a). Critical consumer education: empowering the low literate consumer. Journal of macromarketing, 153-162.

[13]. Anthony Cree, A. K. (2012). The economic and social cost of illiteracy:A snapshot of illiteacy in global context. World literacy foundation.

[14]. Anthony Cree, A. k. (2012). The economic and social cost of illiteracy:A snapshot of illiteracy in global context. final report from the world literacy foundation.

[15]. ARKO, A. D. ( 2009). THE IMPACT OF FUNCTIONAL LITERACY ON SOCIO-ECONOMIC LIVES OF BENEFICIARIES: A CASE STUDY OF THE AGONA DISTRICT OF GHANA. Edo Journal of Counselling Vol. 2, No. 2, , 203.

[16]. ARKO, A. D. (2009). THE IMPACT OF FUNCTIONAL LITERACY ON SOCIO-ECONOMIC LIVES OF BENEFICIARIES: A CASE STUDY OF THE AGONA DISTRICT OF GHANA . Edo Journal of Counselling Vol. 2, No. 2, 203.

[17]. Batra, R. (1999). Marketing issues and challenges in transitional economies. In R. Batra (Ed.), Marketing issues in transitional economies, 3-35.

[18]. Berlin, G. \&. (1988). Toward a more perfect union: Basic skills, poor families and our economic future (Occasional Paper 3). New York: Ford Foundation, Project on Social Welfare and the American Future.

[19]. Bhola, H. (1984). World trends and issues in adult education. London: Biddies Ltd.

[20]. Bormuth, J. (1975). Reading literacy:Its definition and assessment, In J.B Caroll \& J.Chall(Eds.)towards a literate society. 61-100. New York: N Y:McGrawHill. 
[21]. Boudard, E. \&. (2003). Literacy Proficieny of older adults. International Journal of educational reserach, 39, 191-204

[22]. Chingona W, V. b. (2005). usability fctors affecting the adoption of ICT assisted basic adult eduction. ACM international confrence proceeding of human computer interaction in SA, Midrand. Johannesberg.

[23]. Coombs, P. (1985). The world in crisis in education: the view from the eighties. . Trenston: Oxford University Press

[24]. Cunnings, B. (1992). Adult and literacy New York. Haper and Row Publishers.

[25]. Davidson, k. (1990). the Adult Learner. New Jersey: prentice Hall.

[26]. Department of school education and literacy. (n.d.). Retrieved Dec sunday, 2015, from Ministry of human resources developement: http://mhrd.gov.in/adult-education

[27]. Dorvlo, L. T. (1992). Some fundamental issues in functional literacy. Ghana Journal of Literacy and Adult Education. 1(1), 15-28.

[28]. Fox, B. (1990). Antecedents of illiteracy. Society for Research in Child Development Social Policy Report, 4(4).

[29]. Furstenberg, N. B.-G. (JUNE 1994). T E C H N I C A L R E P O R T O P94-01. PHILADELPHIA: NATIONAL CENTER ON ADULT LITERACY, UNIVERSITY OF PENNSYLVANIA

[30]. Gal, I. (1993). Issues and Challenges in Adult Numeracy (Technical Report 93-15). Philadelphia,: PA: National Center on Adult Literacy.

[31]. Gray, W. (1956). The teaching of reading and writing

[32]. Gray, W. (1990). Teaching of reading and writing: An international survey.Chicago: Scott Foresman and Co.

[33]. Guthrie, J. T. (1986). Effects of education, occupation, and setting on reading practices . American Educational Research Journal, $23,151-160$

[34]. Haddad, W. D. (1990). Education and development: Evidence for new priorities. Worht Bank Discussion Paper, No. 95, Washington, 11.C.: World Bank.

[35]. Harber, J. R. (1980). Effects of illustrations on reading performance implications for further LD research.). Learning Disability Quarterly, 3(2, 60-70.

[36]. Harrison-Walker, L. (1995). The import of illiteracy to marketing communication. Journal of consumer marketing, 50-62

[37]. Hunter, C. S. (1979). Adult illiteracy in the United States. New York: McGraw-Hill.

[38]. Institute of statistics, U. (JUNE 2013). ADULT AND YOUTH LITERACY National, regional and global trends, 1985-2015. UIS INFORMATION PAPER, 8

[39]. IRA. (1986). IRA position statement on reading and writing in early childhood. The Reading Teacher, 39, 822-824.

[40]. Jae, H. \&. (2004). Decision making by low literacy consumers in the presence of point of purchase information. The Journal of consumer affairs 38(2), 342-354.

[41]. Kirsch, I. (1986). Literacy: profile of america's young adult. Princeton NJ: national assessmnet of educational progress.

[42]. Kirsch, I. S. (1988). Understanding document literacy: Variables underlying the performance of young adults (RR-88-62) (Research Report). NJ: Educational Testing Service.: Princeton.

[43]. Larrick, N. (1987). Illiteracy starts too soon . Phi Delta Kappan, 69, 184-189.

[44]. Lind, A. a. (1990). A Adult Literacy in the Third World: A Review of Objectives and Strategies. Stockholm: Swedish International Development Agency.

[45]. Madhubalan Viswanathan Carlos J. Torelli, L. X. (2009). Understanding the influence of literacy on consumer memory: The role of pictorial elements. Journal of consumer psychology, 19, 389-402.

[46]. Miller, G. (1988). The challenge of universal literacy. science, 241, 1293-1299.

[47]. Mpofu, S. T. (1995). The outcome and shortfall of the adult literacy and post-literacy project of Zimbabwe 1987-1991. . Zimbabwe Journal of Educational Research. 1(1), 85-113.

[48]. S.M. Burgess, J.-B. S. (2006). Marketing renaissance: How research in emerging markets advances. Intern. J. of Research in Marketing $23,337-356$.

[49]. Scribner, S. a. (1981). The Psychology of Literacy. Cambridge: Harvard University Press.

[50]. Steenkemp, J. \&. (2002). Optimum Stipulation Level And exploratory consmumer behavior in an emerging consumer market. International Journal Of Reserch In Marketing, 19, 131-150.

[51]. Tanguiane, S. (1990). Literacy and Illiteracy in the World: Situation, Trends and Prospects. In International Yearbook of Edu cation, Volume XLII. Paris/Geneva: Unesco/IBE.

[52]. Thompson, A. (1981). Education and development in Ghana. London: Macmillan Educational Ltd.

[53]. UNESCO. (1983). Summary of the international conference on adult education. . UNESCO. Geneva.

[54]. UNESCO. (2006). Literacy for life. Paris, France:UNESCO: EFA global monitoring report.

[55]. UNESCO. (2006). Literacy for life. France: global monitoring report, Paris.

[56]. UNESCO. (2008). Global digest.

[57]. UNESCO. (2009). lamp.

[58]. Wagner, D. A. (1990a). Literacy assessment in the Third World: An overview and proposed schema for survey use. Comparative Education Review 33, 112-138.

[59]. Wagner, D. A. (1992). World Literacy in the Year 2000: Research and Policy Dimensions. . Philadelphia: Annals of the American Academy of Political and Social Science.

[60]. WAGNER, D. A. (1995). LITERACY AND DEVELOPMENT: RATIONALES, MYTHS, INNOVATIONS, AND FUTURE DIRECTIONS . Int. J. Educational Development, Vol. 15, No. 4, 341-362. 